University for Business and Technology in Kosovo

UBT Knowledge Center

UBT International Conference

2017 UBT International Conference

Oct 27th, 4:45 PM - 7:15 PM

\title{
Exploration of housing evolution in Tirana during the years 1929-1943
}

Oketa Hoxha

Polytechnic University of Tirana, oketahoxha@yahoo.com

Florian Nepravishta

Polytechnic University of Tirana, florian.nepravishta@fau.edu.al

Ani Tola(Panariti)

Polytechnic University of Tirana, ani.panariti@fau.edu.al

Follow this and additional works at: https://knowledgecenter.ubt-uni.net/conference

Part of the Architecture Commons

\section{Recommended Citation}

Hoxha, Oketa; Nepravishta, Florian; and Tola(Panariti), Ani, "Exploration of housing evolution in Tirana during the years 1929-1943" (2017). UBT International Conference. 10.

https://knowledgecenter.ubt-uni.net/conference/2017/all-events/10

This Event is brought to you for free and open access by the Publication and Journals at UBT Knowledge Center. It has been accepted for inclusion in UBT International Conference by an authorized administrator of UBT Knowledge Center. For more information, please contact knowledge.center@ubt-uni.net. 


\title{
EXPLORATION OF HOUSING EVOLUTION IN TIRANA DURING THE YEARS 1929-1943
}

\author{
Oketa Hoxha $^{1}$; Florian Nepravishta ${ }^{2}$; Ani Tola $(\text { Panariti })^{3}$ \\ ${ }^{1,2,3}$ Department of Architecture, Faculty of Architecture and Urbanism, \\ Polytechnic University of Tirana, Albania, \\ $\left\{\right.$ oketahoxha ${ }^{1} ;$ f_nepravishta $\left.{ }^{2}\right\} @$ yahoo.com, ani.panariti@fau.edu.
}

\begin{abstract}
This paper traces the evolution of housing typologies, focusing in Tirana, Albania. The study reviews the fundamentals of housing throughout the two historical periods, 1929-1932 and 1939-1943. The housing projects analysed are designed mostly by Austrian and Italian architects. The methodological approach is based on reviewing a number of case studies starting from onefamily house to multi-family housing typology. The main purpose of this paper is to identify the process of transformation and development of housing based on the typologies, functionality, and occupancy. Also, particular elements of asthetics are analyzed and compared. This study highlights that the improvement of living conditions happened because of a better design and situation of housing in an urban context.
\end{abstract}

Keywords: Housing, Villas, Italian-Austrian architecture, Occupancy

\section{Introduction}

Housing transformations worldwide are the results of socio-political and socio-economic changes. In the case of housing typologies in Tirana has been a direct expression of state policies and its relationship with some countries of Europe. The community and environmental conditions are the other producers of housing typologies.

A considerable influence of foreign architects started when Tirana was chosen the capital city of the country. The first arrangement plan was drawn up in 1923. The Austrian architects were very present in Tirana during 1927-1932, until when Italians arrived in Albania in 1939.

The years 1939-1943, even though included in the time span of Second World War, are full of important undertakings with regard to projects and visions on an urban scale for Tirana. In April 1939, Italy invades Albania. In September of the same year, Second World War started. After these events, Albania continues to be a country of its own but it is united with Italy under the Reign of King Victor Emanuel III (until his abduction in July 1943). [1]

The most notable Italian architects were involved in the designs of modern Tirana, like Gherardo Bosio (1939), Ivo Lambertini, Armando Brasini (1926) and Ferdinando Poggio (1943). One of the main requirements of the Regulatory Plan of 1942, that marked the redesign of the Old Tirana in metropolitan dimensions, was the uncial composition of the city garden. The idea of 'citta giardino' (city garden) was combined with the purpose to convert the urban chaos of a village in a western city. [2] 


\section{Methodology}

The main purpose of this paper is to explore the transformation of the dwelling's layout and its interior spaces from 1929 to 1943 . This study is descriptive and analytic. At the beginning it provides the data of housing typologies from Austrian architects in the years 1929-1932 and then the housing typologies for Italian Official's from 1939 up to 1943. The typological classification is based on the specific qualities of the dwellings that identify their characteristics in order to establish the differences between them. The investigation of typological transformation and evolution in the selected case studies in Tirana applies a multi-layered methodological approach that involves the two following fazes:

- Identification of two historic periods that had significant impacts on housing

- Classification and comparison of the dwellings from 1929 to 1943

These two fazes are very important to realize the third faze wich is the typological analyze of housing evolution in Tirana. Nine samples of housing types were selected from a wide variaty of houses that represent succesive historic eras in the capital city. After a detailed study of all samples, 4 examples are selected to represent the period of Austrian architects from 19291932 and 5 examples to represent the period where italian architects worked for Albania from 1939-1943.

The first period is represented by single and double houses (building with two houses inside it). It starts with house with two rooms and finishes with a single house with six to eight rooms.

Beside the singular houses, multi-storey buildings were introduced as residential models in the second period that is taken in consideration.

The samples that are in this paper represent the majority of housing models of formal designed dwellings during the years 1929-1943 in Tirana. In this study, not all the models were covered but only some typical cases.(Fig.1)

The architectural plans reveal the typological transformation of the housing and the exact way in which the residential buildings were designed by architects in each period. 


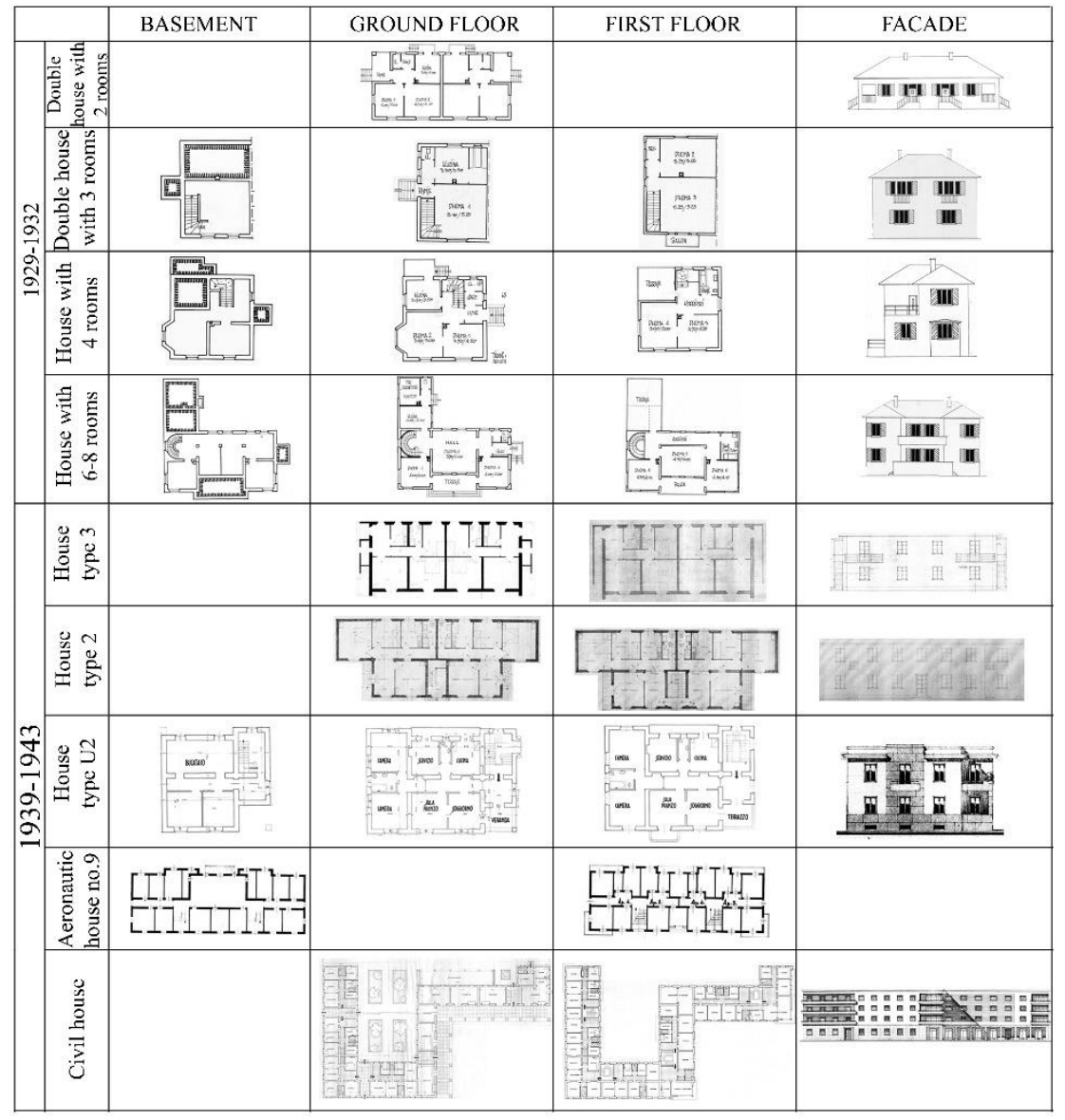

Fig. 1. The various case studies of housing in Tirana.

The typological housing evolution is conducted by graphically analysing the types in order to detect the evolutionary characteristics of each example between two periods. In this paper the analyse is focused mostly on the ground floor of the housing unit and dwellings. The houses that are chosen to be shown in the paper are completed with plans and facades in order to create a better idea of their existing situation. The procdure of methodology is based on observation and interpretation for each case.

\section{Materials}

The period 1929-1943 was an important part of history and architecture to be mentioned and treated in nowdays. All the projects of these years are very contemporary and quiet different from the socialism period that was established in Albania after the 1944.

Socialist architecture has produced for years a rigid and standardized typology, even randomly pure and primitive architectural prototypes, except for some objects of public importance. 
Albanian architects guided from the socialist realism ideology were very rigid in the development of the modern ideas. [3]

All the samples presented in the paper are designed to be built in Tirana and some of them are standard cases so that they could be used in different places and urban situation. Some of them, especially the samples from Italian architects are particular houses because of their urban context and the people chosen from the Government to live in them. After the year 1939 the collective houses in Tirana were designed for officials and they were placed not only in the centre of the Capital city but also in the peripheral zones of Tirana.

Collective houses for officials were proposed at the area of 'New Tirana' in the southwest between the Fasho's offices and Lana River (Fig.2). [4]

In order to precede the vast expansion of the city, the plan predicted private buildings and extra urban zones as complementary neighborhoods around Tirana in order to make it as a parkland city. This zones consisted in the northern part of the river in Tirana, which nowadays is the hills of Paskuqan (nowadays it is an informal place of residence Bathore-Paskuqan) as well as on the hills in the south and east of Tirana. This plan also included Lapraka, which at that time was called 'Villaggio Littorio' (Fig. 2).[4]

\section{Housing typologies of the first period, 1929-1932}

As it is mentioned before the houses of this period are mostly designed by Austrian architects and the samples of this paper are all designed by architect Kohler.

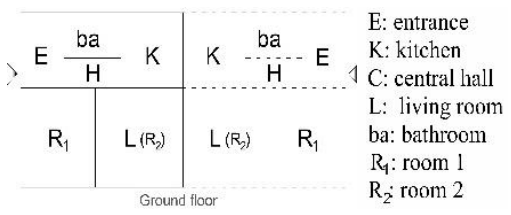

Fig. 2. The schematic plan of ground floor of the double house with two rooms and the relevant legend. Source: Author

This house is designed in the year 1929 by the Austrian architect: Kohler. It is a one floor building with two apartments and each apartment has two rooms. |This is the smallest unit for apartment designed before 1944 in Tirana. (Fig. 2.)
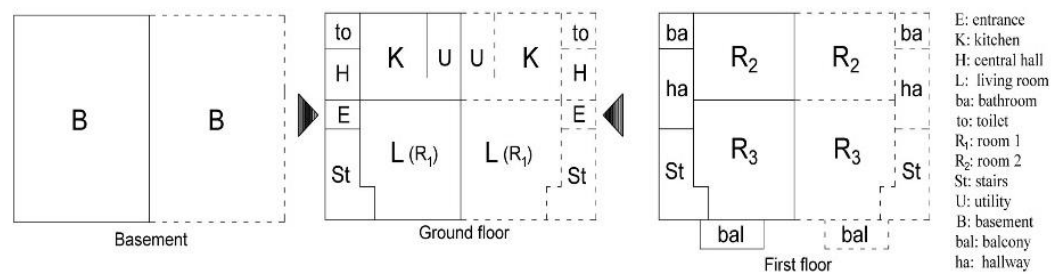

Fig. 3. The schematic plans of the double house with three rooms and the relevant legend. Source: Author 
The example of house with three rooms is concepted with basement, two apartments for each floor and it goes up to two floors. Each aprtment is organised with inside stairs that connect vertically the basement with the ground floor and this one with the first floor. (Fig. 3.)

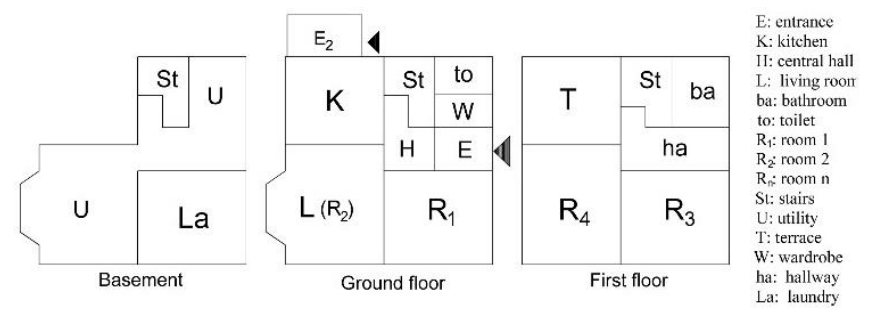

Fig. 4. The schematic plans of the single house with four rooms and the relevant legend. Source: Author

The typical house with four rooms is designed for one family only and it has two floors above and one under ground. (Fig. 4.)

The example with 6-8 rooms is similar to the above house but bigger in sufaces and more comfortable because of the biger number of rooms and ambjents inside it. Both cases go up to two floors plus the basement.

\section{Housing typologies of the first period, 1939-1943}

The Italian architects were very careful in designing housing typologies in Tirana becuse of the importance they gave to the urban context. They tried to improve the social and physical conditions of the residents in those years. The imediately growth of the number of officials that came to Albania made the architects to design urban plans and many residences inside them. Some buildings were builted with many apartments in each floor and went up to six floors high.

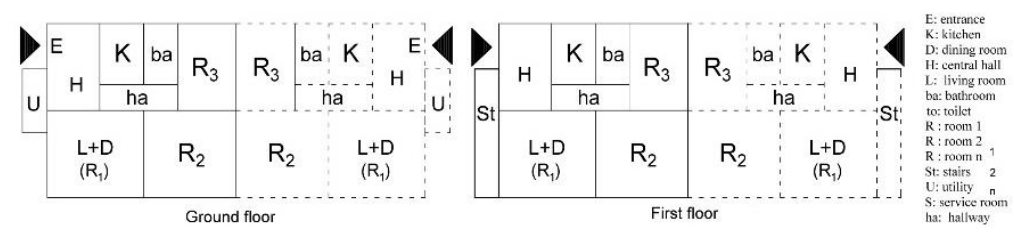

Fig. 5. The schematic plans of the house type 3 and the relevant legend. Source: Author

The house type 3 is a typical house designed for Littorio village, located at south and east of Tirana. Due to increasing number of the Italian officials populating Tirana city and the need for immediate accommodation started to implement a new idea of converting the villas into apartments. These buildings have to accommodate more than one family so floors were shared among two families. The number of floors of these buildings was two. (Fig. 5.) 

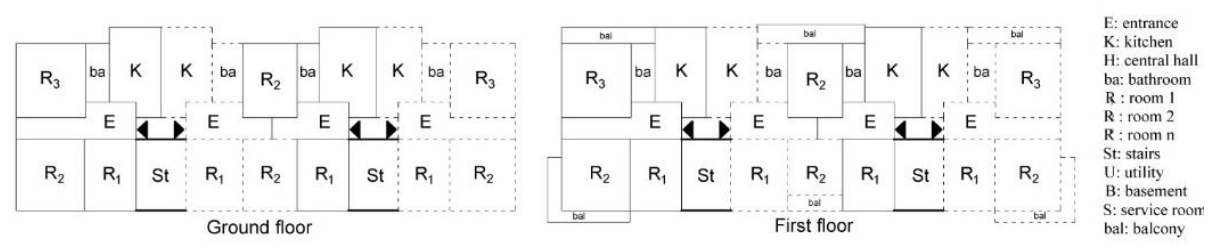

Fig. 6. The schematic plans of the aeronautic building number 9 and the relevant legend. Source: Author

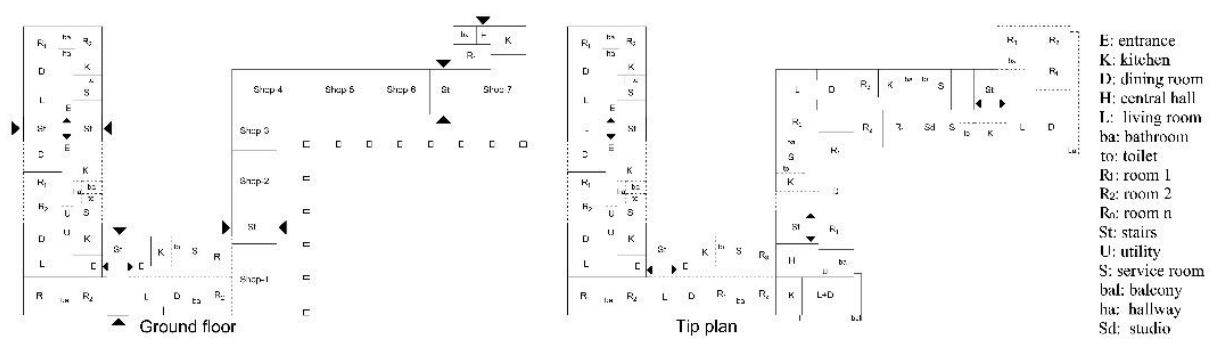

Fig. 7. The schematic plans of the civil building and the relevant legend. Source: Author

The last two samples presented in the paper are positioned in New Tirana. They are typical examples of multi families buildings. All the apartments have all the necessary areas for good social and physical conditions for each family. (Fig. 6., Fig. 7.)

The first case where the apartments and shops are designed in the same floor is the civil building. This happened in the ground floor because the other floors are only with apartments.

\section{Conclusions}

The evolution of housing from 1929 to 1943 is quiet evident not only in shape but also in content. As presented in this paper the housing typologies began in 1929 with simple houses which were designed with single or maximum two apartments per house. The present of two apartments in the same building limited the areas and conditions of each apartment. As a result the houses before the year 1932 could not complete all the necessity that a family need to live in community. After the year 1939 the architects tried to adapt the house in a real urban plan, giving so every family the possibility to live in better conditions and in urbanized areas. This was realized when the shops and apartments were integrated in the same building because of the facilities they offered to the citizens. The increase of number of apartments per building is obvious, from two apartments in all the house in 1929 to 28 (twenty eight) apartments in the dwellings designed in the years 1939-1943. The transformation process of the plans described in this paper is to show that it is not simply the changing arrangement of rooms inside each apartment but the interaction between the apartments and shared spaces that define the evolution of plans and houses. The analysis of nine samples presented in this study reveals that in the years 1929-1932 the buildings were designed up to two floors and arrived to four floors in 1943. The evolution of house is present in plans, facades and volumes. 


\section{References}

1. Vokshi A.: Trace of Italian Architecture in Albania 1925-1943, (Tracce dell'Architettura Italiana in Albania 1925-1943), DNA Editrice, Firenze (2014)

2. Resuli P., Dervishi S. Architectural Decorative Elements of Tirana, Traditional Villas: The Italian Impact, 2nd ICAUD International Conference in Architecture and Urban Design, Epoka University, Tirana, Albania, 08-10 May 2014, Paper No. 255

3. LuloK.,TummersK.,(2012)."Architecture and Urban Planning," History of Albanian Architecture Model[online]at www.seda.org.al/download/i/.../2.3- Architecture.pdf (accessed on 10/10/2015)

4. Dhamo S., ThomaiGj., Aliaj B.: Tirana,Missed City, (Tirana Qyteti i munguar), Pegi, Tirane (2016) 104-122 